\title{
The Jigsaw Method in Didactical Analysis of Indonesian National Songs by W.R. Supratman at Fifth Grade Students PBSI FKIP-USI
}

\section{Berlian Romanus Turnip}

Lecturer, LLDikti Wil.I Sumut dpk, FKIP-USI, Indonesia

\begin{abstract}
This research aims 1)to determine the student's ability in analyze the didactic values of Indonesia Raya national song before the application of the jigsaw method. 2)to find out the student's ability in analyze the didactic values of the Indonesia Raya national song after the application the jigsaw method. 3)to determine the effect of the jigsaw method in analyzing the didactic values of the Indonesia Raya national song. The method used in this study is the experimental method and the sample in this study were all students of the Language and Literature Education Study Program (PBSI), Faculty of Teacher Training and Education (FKIP) Simalungun University (USI) totaling 30 students. The result of this research shows that the ability in analyze the didactic values of the lyrics national song "Indonesia Raya" by Wage Rudolf Supratman in experimental group is sufficient with an average score of 66.50 and in control group is sufficient with an average score of 61, 83. The Comparison in the experimental and control groups is sufficient with average score of 64.17. There is a positive and significant influence ability to analyze the didactic values of the national song "Indonesia Raya" by Fifth Grade Students PBSI FKIP-USI in experimental group using the jigsaw method $\left(t_{\text {count }}>t_{\text {table }}(0.05)\right.$, was $\left.4.05>2.00\right)$. $t_{\text {count }}>t_{\text {table }}$ value, then the alternative hypothesis $($ Ha) is accepted there is a positive and significant effect the application of the jigsaw method in learning to analyze the didactic values of national song "Indonesia Raya" by Fifth Grade Students PBSI FKIP-USI.
\end{abstract}

Keywords—Jigsaw Method, Didactica Value, Song.

\section{INTRODUCTION}

The whole educational process play the most decisive role in producing students. Their duties as educators, the role of lecturers is not only limited activities in the classroom but broader. The role of lecturers very large in developing insights into the thoughts of students, which can be seen from their teaching activities. Lecturers who are diligent carrying out teaching activities mean they are sincere and responsible for their duties. Conversely, a lecturer who neglects teaching activities means duties and responsibilities. Good teaching are activities that can be carried out effectively. With effective teaching, carried out by lecturers, especially teaching Indonesian, will be carried out well. Conversely, ineffective teaching will cause some objectives that have been set cannot be achieved optimally.
Suite (1986: 4) says: "It is clear that between language and literature there is a very close relationship that cannot even be separated. Therefore, presentation informal education, literature, and language cannot be separated. Literature is given another aspect of language teaching, namely listening, speaking, reading, and writing to support broad and comprehensive goal of language teaching, namely students have language knowledge, abilities, and language skills. Norman and Alpon in Suyitno (1986: 1) also say: "Literature is source of knowledge including language knowledge, a source of beauty and a mirror of community life that is presented to students. The aim to train the four language skills, increase knowledge about human life experiences, can also provide attitudes, ways of thinking, and behavior " 
Learning the values of songs is actually often learned in schools / formal educational institutions, but it is very unfortunate, in the real world, students still find difficult to understand the values contained song lyrics. Losing the meaning of the national anthem for the majority of citizens for a long time, the result weakening the national spirit, and decreasing the sense of nation and state.

\section{REVIEW OF LITERATURE}

\section{Definition of Jigsaw}

Jigsaw comes from English, namely jigsaw and some call it the term puzzle, which is a puzzle that arranges pieces of an image. This jigsaw cooperative learning model also takes a pattern of how to work a chainsaw (jigsaw), where students do learning activities by collaborating with other students to achieve common goals.

The jigsaw cooperative learning model is a cooperative learning model that focuses on group work of students in the form of small groups, as stated by Lie (1993: 73), the jigsaw is a cooperative learning model which students learn in small groups consisting of four to six people heterogeneously and students cooperate have positive interdependence, responsible independently. Each student in the "initial group" specializes in one part of a learning unit. The students met with other group members who were assigned to work on other parts, and after mastering this other material they would return to their initial group and inform the other members of the material.

All students in the "starting group" have read the same material and they meet and discuss it to ensure understanding. They move to a "jigsaw group", where members come from other groups who have read different parts of the assignment. In this groups, they share knowledge with other group members and learn new material. After mastering this new material, all students return to the "starting group" and each member shares the knowledge they learned in the "jigsaw group. Jigsaw is an active learning technique that is commonly used because maintains a high level of personal responsibility.

\section{Jigsaw Cooperative Learning Steps}

According to Rusman (2008: 205), the jigsaw learning model also known as cooperative experts, because members of each group are faced with different problems. However, the problems faced by each group are the same, they are referred as a team of experts in charge of discussing the problems at hand. Next, the results of the discussion are taken to the original group and conveyed to the group members. The activities carried out in the jigsaw cooperative learning model as follows: (1) Reading to dig up information. Students get problem topics to read so they get information on these problems; (2) Expert group discussion. Students who have received the same problem topic meet in a group called a group of experts to discuss the topic of the problem; (3) The group report, the expert group returns to the original group and explains the results obtained from the expert team discussion; (4) The quiz is conducted covering all the topics that have been discussed earlier; (5) Calculation of group scores and determining group rewards.

According to Stepen, Sikes and Snapp (1978) quoted by Rusman (2008), suggested the steps of the jigsaw cooperative learning model are as follows: (1) Students are grouped into 5 students; (2) Each person in the team is given a different part of the material; (3) Each person in the team is given an assigned part of the material; (4) Members of different teams who have studied the same subsection, meet in a new group (expert group) to discuss their subsections; (5) After finishing the discussion the team of experts, each member returns to the original group and takes turns teaching their teammates about the sub-chapters they have discussed and each other member listens carefully; (6) Each team of experts presents the results of the discussion; (7) the lecturer gives evaluation; and (8) Closing.

\section{Meaning of the song}

Every country has its own national anthem because the national anthem is an expression of the soul of a nation. The national anthem occupies a special position and respected by all its people. The national anthem is always sung or played at every official state event, and also at every event abroad that carries the name of the country. Indonesia, the national anthem is often pronounced at official events, both state and formally in schools and other institutions of an official nature. The song "Indonesia Raya" by W.R. Supratman, is the national anthem for all Indonesian people, a song that is respected and proud of national spirit generator, and there is an extraordinary feeling of devotion in its soul. In the colonial era, the colonialists forbade the people to sing this song, but the people ignored it and continued to sing it, so that it increased the spirit of nationalism, a sense of nationality, a sense of common sense, and a sense of struggle, as well as strengthening unity against colonialism. 
Now, many residents and students do not show physical respect when singing or listening to the song Indonesia Raya, whereas only respecting inwardly is certainly not real and invisible. This fact shows that education does not give weight to the material of nationalism, does not instill a national spirit, does not train themselves to respect the symbols of the state, so they are less proud to have an independent nation and less proud to have a national anthem. Whereas education in Indonesia, since the beginning of independence, has adhered to the teachings of Ki Hajar Dewantara which is full of values of struggle and values of nationalism.

\section{RESEARCH METHODOLOGY}

The method used by researchers is the experimental method or the treatment of activity, namely applying the jigsaw learning method $(\mathrm{X})$ to the students' ability at the fifth grade semester analyze the didactic values of the national song "Indonesia Raya" (Y). The population as well as the sample in this study were all students of the Language and Literature Education Study Program (PBSI), Faculty of Teacher Training and Education (FKIP) Simalungun University (USI) in Academic Year 2018/2019, totaling 17 people.

\section{FINDING AND DISCUSSION}

\section{Finding}

In accordance with the problems studied, the data described the students' ability to analyze the didactic values of the national song "Indonesia Raya" by Wage Rudolf Supratman, the data description is divided into three parts, namely:

1. The ability of fifth semester students to analyze the didactic values of the national song "Indonesia Raya" in the experimental class apply of the jigsaw method.

2. The ability of fifth semester analyzed the didactic values of the national song "Indonesia Raya" in the control class not apply the jigsaw method.

3. The ability fifth semester students to analyze the didactic values of the national song "Indonesia Raya" in the control class not apply the jigsaw method.
Based on the research data analysis above, the research findings are as follows:

1. The average score (Mean) ability to analyze the didactic values of the national song "Indonesia Raya" by fifth semester in the experimental group is 66.50 which means that the students' abilities are sufficient.

2. The average score (Mean) of the ability to analyze the didactic values of the national song "Indonesia Raya" by fifth semester in the control group is 61.83 which means that the students' abilities are sufficient.

3. The comparison of the average score (Mean) ability to analyze the didactic values of the national song "Indonesia Raya" by fifth semester in the experimental and control groups is 64.17 which means that the students' abilities are classified as enough.

4. The results of the data normality test ability to analyze the didactic values of the national song "Indonesia Raya" in the experimental group, the value of $\chi^{2}$ count $<$ $\chi^{2}$ table (0,05), was obtained, namely $5.210<11.070$ (normally distributed data). the ability to analyze the didactic values of the national song "Indonesia Raya" in the control group, the value of $\chi^{2}$ count $<\chi^{2}$ table $(0,05)$, was obtained, namely $8.291<11.070$ (data normally distributed).

5. The results of the research variable homogeneity test, it was obtained that the value of $F_{\text {count }}<F_{\text {table }}(0,05 \%)=$ $1,35<1,85$, which means that the research variable has a homogeneous variance.

6. There is a positive and significant influence on the ability to analyze the didactic values of the national song "Indonesia Raya in experimental and control groups using the jigsaw method ( $\mathrm{t}$ count $>\mathrm{t}_{\text {table }(0,05) \text {, was }}$ $4,05>2,00$ ).

7. Because the value of $t_{\text {count }}>t_{\text {table }}$, it can be concluded that the alternative hypothesis ( $\mathrm{Ha})$ is accepted there is a positive and significant effect of the application of the jigsaw method in analyzing the didactic values of the national song "Indonesia Raya"

\section{Discussion}

The song is a literary work that blends with the art of sound. Poetry is the verse containing the messages the poet wants to convey to others. To create a special attraction, the poetry is sung in certain tones and is often accompanied by music. There are song lyrics that are easy to understand, but some are not understood by students. This is because in 
conveying messages to other people, song poets use language that has connotative meaning (figuratively). Of course, song lyrics that have connotative meanings often lead to differences in interpreting the classical meaning of the song lyrics.

In fact, because the song is pleasant to hear, people often ignore the classical meaning of the song. If the above happens, then art connoisseurs will not get the messages conveyed by the poets, without exception the values contained in the song's lyrics. Wage Rudolf Supratman is an artist who is well-known in the Republic of Indonesia because the lyrics of his songs can inspire listeners. One of the values that are often raised in the song Indonesia Raya is the national value that teaches all Indonesians to instill awareness through song lyrics Indonesia, my native land The land where I shed my blood Right there, I stand To be the guide of my motherland My mother said she meant the motherland or legal government. This sentence instills awareness that a legitimate government has a very big responsibility in playing a role as a guide/guide/mentor for all citizens to improve the welfare of all its citizens. That the attitude of every citizen towards the motherland must behave the same as the attitude towards the biological mother/parents.

Likewise with poetry Indonesia, my nationality ,My nation and my homeland. These two sentences instill awareness that every citizen has a nationality, namely Indonesian nationals, Indonesian citizenship. That every citizen takes a firm stance in acknowledging that he is Indonesian nationality and has an Indonesian homeland.

Let us exclaim “Indonesia unite!". These two sentences instill awareness that every citizen exclaims, acts, and tries to foster the unity and integrity of Indonesia so that Indonesia is truly united, whether through daily attitudes, words, behavior, and actions. That every citizen tries his best to keep away all things that can divide Indonesia.

Long live my land, Long live my country, My people, everything. This stanza consists of four sentences to instill awareness that every citizen always tries to make Indonesia a homeland that lives for an unlimited time. That every citizen, every citizen, everything, must be a citizen who is truly alive, truly dynamic, and creative to change the situation so that the situation always changes for the better. That all the people, all citizens try not to let the people die and try so that Indonesia does not die, become extinct or dissolve.
Wake up his soul, Wake up his body. These two sentences instill the awareness that every citizen prioritizes trying to build a national spirit, the spirit of nationalism, the spirit of the nation and state, a very prime spiritual mentality, and is a top priority. That every citizen also builds his body, carries out physical development to the maximum for physical and mental well-being.

For Indonesia Raya. This sentence instills awareness that every citizen, in doing business in all fields, must be an integral part of an activity in a grand strategy for the development of Indonesia as a whole. That all citizens in carrying out their business in any field must advance together, go hand in hand towards Great Indonesia, must work together with each other, and efforts must be made that there should be no interfering with each other.

Free Indonesia Raya. In this sentence the word Merdeka is pronounced twice, instilling awareness that the entire territory of Indonesia must be truly independent, there is no more colonialism, invasion from foreign parties, there is no control of the area by foreigners. That every citizen must strive for no more colonialism in all parts of Indonesia in any form, in any field.

Tanahku is the country that I love, this sentence instills awareness: that every citizen in all his efforts to achieve, produce, create, innovate based on his love for his country and homeland.

Long live Indonesia Raya, this sentence instills awareness: that the highest ideal of every citizen is an Indonesia that is able to struggle to live for an unlimited time, able to compete in international globalization in all fields. And Indonesia continues to live as a large country and is a country that is favored by the international community.

Based on the results of research conducted on research respondents, namely class $\mathrm{X}$ students of Fifth Grade Students PBSI FKIP-USI in analyzing the didactic values of the national song "Indonesia Raya", it turns out that their abilities vary, some are good, adequate, lacking, and very less. From the two groups of research respondents, it is known that the students' ability to analyze the didactic values of the song "Indonesia Raya" was higher in the experimental group than in the control group with an average value ratio of 66.50: 61.83. This value indicates that students find it easier to analyze the didactic values of the song "Indonesia Raya" by applying the jigsaw method. And based on the observations of researchers, it turns out that the lyrics of the 
song "Indonesia Raya" seem to contain more didactic values to make the Indonesian people aware of their homeland.

The general ability of students for the second group of research respondents, both experimental and control groups in analyzing the didactic scores of the national song "Indonesia Raya" was sufficient. The predicate "sufficient" indicates that the students analyzed the song lyrics not as expected. Ideally, the student's ability to analyze the song is good, not enough.

\section{CONCLUSION}

After discussing the problems studied, the following conclusions were obtained:

1. The ability in analyze the didactic values of the lyrics national song "Indonesia Raya" by Wage Rudolf Supratman by Fifth Grade Students PBSI FKIP-USI the experimental group is sufficient with an average score of 66.50 .

2. The ability in analyze the didactic values of the lyrics of the national song "Indonesia Raya" by Wage Rudolf Supratman by Fifth Grade Students PBSI FKIP-USI the control group is sufficient with an average score of 61,83 .

3. The Comparison ability in analyze the didactic values of the lyrics of the national song "Indonesia Raya" by Wage Rudolf Supratman by Fifth Grade Students PBSI FKIP-USI in the experimental and control groups is sufficient with an average score of 64.17. There is a positive and significant influence on the ability to analyze the didactic values of the national song "Indonesia Raya" in the experimental group using the jigsaw method $\left(\mathrm{t}_{\text {count }}>\mathrm{t}_{\text {table }}(0.05)\right.$, was 4.05> 2.00)then the alternative hypothesis (Ha) is accepted there is a positive and significant effect of the application the jigsaw method in learning to analyze the didactic values of the national song "Indonesia Raya" by Fifth Grade Students PBSI FKIP-USI.

\section{REFERENCES}

[1] Arsyad, Maidar G. dkk. 1986. Buku Materi Pokok Kesusasteraan II. Jakarta: Karunika Universitas Terbuka.

[2] Ali, Lukman. 1979. Pengembangan Apresiasi Puisi. Jakarta: Gramedia.
[3] Arikunto, Suharsimi. 1982. Prosedur Penelitian Suatu Pendekatan Praktik. Jakarta: Rineka Cipta.

[4] Darma, Budi. 1984. Sejumlah Esai Tentang Sastra. Jakarta: Gramedia.

[5] Effendi, S. 1974. Bimbingan Apresiasi Puisi. Ende Flores : Nusa Indah.

[6] Gani, Rizanul. 1980. Pengajaran Apresiasi Puisi: Pengajaran Bahasa dan Sastra. Tahun V, No.2.

[7] Hartoko, Dick dan B. Rahmanto. 1985. Memanusiakan Manusia Muda. Jakarta: BPK Gunung Mulia.

[8] Lubis, Abdul Hamid Hasin. 1988. Glosarium Bahasa dan Sastra. Medan : FKSS.

[9] Luxemburg, Jan Van. 1992. Pengantar Ilmu Sastra. Jakarta: PT. Gramedia.

[10] Purqo, Bambang Kaswanti. 1991. Bulir-bulir Sastra dan Bahasa. Yokyakarta: Kanisius.

[11] Semi, Atar. 1988. Kritik Sastra. Bandung: Angkasa.

[12] Simatupang, B. 1980. Apresiasi Sastra: Makalah. Yokyakarta: UGM.

[13] Situmorang. B.P. 1981. Apresiasi Puisi Kontemporer. Ende Flores: Nusa Indah.

[14] Sumardjo, Jacob.1979. Sebuah Saran Tentang Model Buku Apresiasi di Sekolah Lanjutan. Pengajaran Bahasa dan Sastra. Tahun V, No.2.

[15] Surakhmad, Winarno. 1982. Pengantar Penelitian Ilmiah; dasar, metode dan Teknik. Bandung: Tarsito.

[16] Suryabrata, Sumadi. 1994. Metodologi Penelitian. Jakarta: Raja Grafindo Persada.

[17] Tarigan, Henry Guntur. 1993. Prisip-prinsip Dasar Sastra. Bandung: Angkasa. 